\title{
EVALUATION OF THE CONDITIONING TO DETERMINE THEIR THERMAL COMFORT IN THE EDUCATIONAL INSTITUTIONS OF THE PUNO REGION
}

\author{
Mercedes Galarza \\ Federico Villarreal University EUPG- UNFV- Lima, (Peru). \\ E-mail: 2020005182@unfv.edu.pe \\ ORCID: https://orcid.org/0000-0002-7186-9619
}

\begin{abstract}
Doris Esenarro
Federico Villarreal University EUPG- UNFV- Lima, (Peru). Ricardo Palma University URP- Lima, (Peru). Specialized Institute for Ecosystems and Natural Resources

Research (INERN), (Peru).

E-mail: desenarro@unfv.edu.pe

ORCID: https://orcid.org/0000-0002-7186-9614
\end{abstract}

Jose Livia

University National University Federico Villarreal UNFV, (Peru).

E-mail: jlivia@unfvedu.pe

ORCID: https://orcid.org/0000-0002-4681-3440

\begin{abstract}
Elizabeth Segovia
Federico Villarreal University - Ecotourism School, UNFV- Lima, (Peru). Specialized Institute for Ecosystems and Natural Resources Research (INERN), (Peru).

E-mail: esegovia@unfv.edu.pe ORCID: https://orcid.org/0000-0002-8790-6707
\end{abstract}

Recepción: 10/09/2021 Aceptación: 05/11/2021 Publicación: 14/02/2022

\section{Citación sugerida:}

Galarza, M., Esenarro, D., Livia, J., y Segovia, E. (2022). Evaluation of the conditioning to determine their thermal comfort in the educational institutions of the Puno region. 3C Tecnología. Glosas de innovación aplicadas a la pyme, Edición Especial, (febrero 2022), 151-165. https://doi.org/10.17993/3ctecno.2022. specialissue9.151-165 


\section{ABSTRACT}

This research aims to evaluate the conditioning that determines the thermal comfort in the Educational Institutions of the Puno Region. The schools of the study site lack thermal comfort due to the existing low temperatures, so the study evaluates the conditioning that allows determining the thermal comfort in the Educational Institutions of the Region. The methodology used in this context is experimental since measurements have been made in situ, obtaining results that allow comparing and demonstrating the use of passive materials in the classrooms to improve the interior conditioning, bringing; as a result, an efficiency of $85 \%$ as a conclusion we can say that the implementation of passive materials inside the classrooms, helps to improve thermal comfort.

\section{KEYWORDS}

Thermal, Thermal conditioning, Comfort, Thermal comfort. 


\section{INTRODUCTION}

Thermal comfort is a neutral sensation of the person concerning a given thermal environment. According to ISO 7730, thermal comfort "is a mental condition in which satisfaction with the thermal environment is expressed. The high Andean areas of Peru have a cold climate during most of the year, with temperatures below freezing. Therefore, the premises for educational use are primarily built with techniques that do not take into account the low levels of environmental temperature, which could lead to the development of a series of infectious diseases among students that would limit their academic performance (Hinojosa et al., 2021).

The development of the research will provide better living conditions for the population and as a result of this the reduction of morbidity and mortality caused by Acute Respiratory Infections (ARI), "Pneumonia being the disease that produces more deaths in Peru, according to the report published in 2013 by the Institute Health Metrics and Evaluation (IHME), which studies the causes of premature deaths in 1990 and 2010. A health problem that mainly affects children under five years old and adults over 65 years old. From 2009 to 2013, the departments with the highest lethality due to pneumonia have been Puno, Huancavelica, Junín, Ayacucho, Gusco and Huánuco” (Umán \& Méndez, 2019).

It is for this reason that the present work conducts a study of the educational premises, identifying and analyzing the environmental and constructive characteristics and technical perception of the users inside the classroom and proposing alternatives that overcome the ecological limitations of the school premises, providing them with elements that insulate the classrooms from the cold and thus protect the children who attend them. The contribution of this research, through the study carried out in the educational premises of Puno, is to propose an alternative solution to improve the management of the conditioning process and thermal comfort inside the existing classrooms in the study area through a passive air conditioning system according to the social, cultural and environmental characteristics of these (Esenarro et al., 2021) For which air conditioning strategies will be taken into consideration with the use of natural energies, which are inexhaustible resources and do not generate polluting emissions (Norma EM.110, 2014). 


\section{METHOD}

The methodology used is experimental due to manipulating the variable temperature vs. materials to achieve the required results at the study site (Belón, 2018).

\section{Study area}

The study was carried out in Peru, in the city of Puno.

IE $\mathrm{N}^{\circ}$ 72312, G.P. Tiquitiqui is located in Altoandino at 3,889 m.a.s.l., Inchupalla District, Huancané Province, Puno Region (Figure 1).
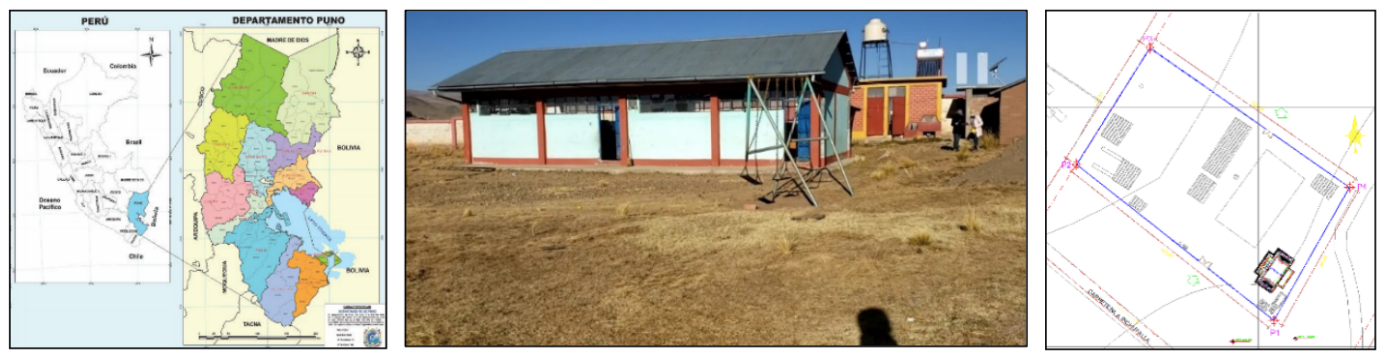

Figure 1. Location of the study area.

Source: own elaboration.

Current temperature inside the IE 72312, C.P. Tiquitiqui is located in Altoandino at 3, 889 m.a.s.l., Inchupalla District, Huancané Province, Puno Region (Flores \& Quispe, 2017).

\section{The temperature inside the classroom}
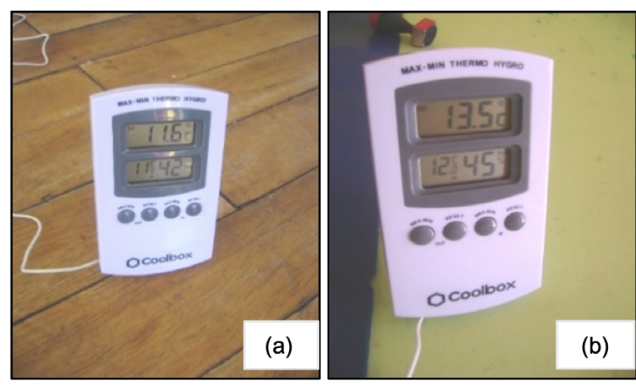

Figura 2. (a) at $8.50 \mathrm{am}$ it is $11.6^{\circ} \mathrm{C}$. (b) At $10.50 \mathrm{am}$ it is $13.5^{\circ} \mathrm{C}$.

Source: own elaboration. 


\section{Type of Research}

The quantitative research will analyze the facts before and during the implementation of conditioning materials, explore the thermal comfort inside the classrooms. From the information, the results will be obtained to determine the types of the proposed materials (Quispe, 2015).

\section{Procedure}

For the present investigation, a field survey of the School Premises is carried out. Once the field survey has been carried out, the types of materials found and their state of conservation is verified (Quispe, 2013).

\section{Results}

The results are that temperatures increase from $1{ }^{\circ} \mathrm{C}$ to $5^{\circ} \mathrm{C}$ inside each classroom.

Table 1. Table of Existing Materials-Interior Floors.

\begin{tabular}{|c|c|c|c|}
\hline \begin{tabular}{|c|} 
1.- What is the current state of conservation of \\
the classrooms - INTERIOR FLOORS?
\end{tabular} \\
\hline Field Trip & $\begin{array}{r}N^{\circ} 10 \text { of } \\
\text { Respondents }\end{array}$ & $\begin{array}{c}\text { Percentage } \\
100 \%\end{array}$ \\
\hline Well & 1 & $10 \%$ \\
\hline Fair & 6 & $60 \%$ \\
\hline Bad & 3 & $30 \%$ \\
\hline TOTAL & 10 & $100 \%$ \\
\hline
\end{tabular}

Source: own elaboration.

In Table 1, Existing interior floors of the classrooms, it can be seen that $10 \%$ are in good condition, $60 \%$ of the existing base is in fair condition, and $30 \%$ is in a poor state of conservation (Bojórquez, 2010).
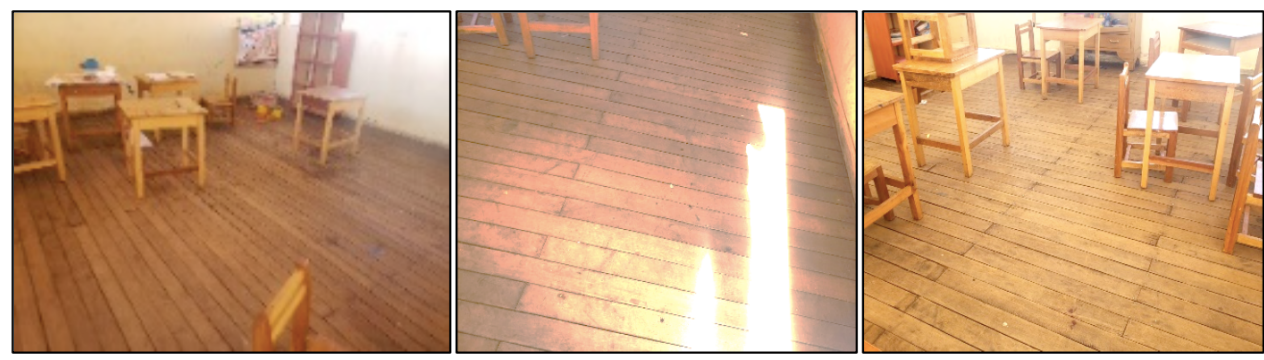

Figure 3. Existing interior floors.

Source: own elaboration. 
Figure 3 shows the materials used, such as tongue and groove wood 1 " $x 4$ ", placed on wooden sleepers, with a poor concrete base, set on natural soil.
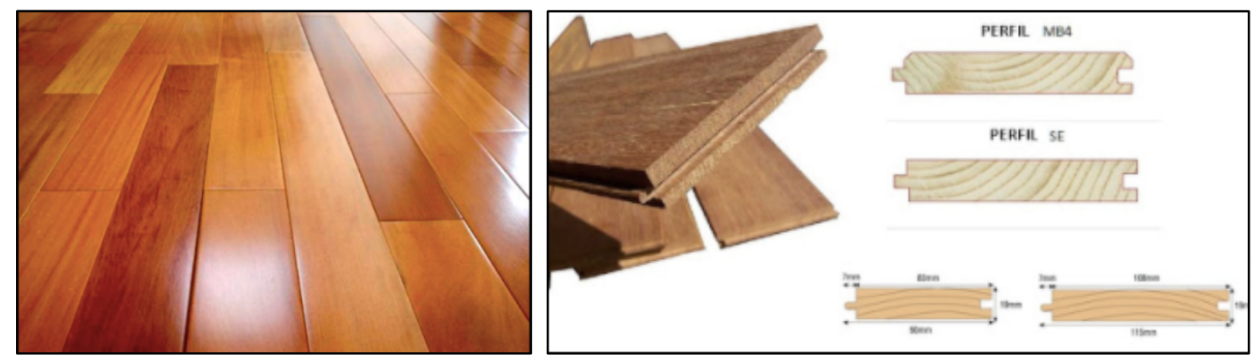

Figure 4. New interior floors.

Source: own elaboration.

Figure 4 shows the removal of existing 1 " $\mathrm{x} 4$ " tongue and groove wood + wood sleepers + lean concrete base. New 3/4 "x4" wood screw tongue and groove floor + sealer + wood preservative $+\mathrm{dd}$ varnish. Concrete false floor $\mathrm{e}=4$ ", on compacted granular material + sawdust + plastic sleeve and wood sleepers screw 2 "x3" (MINEDU, 2008).

Table 2. Table of Existing Materials-Windows.

\begin{tabular}{|c|c|c|}
\hline $\begin{array}{r}\text { 2.- What is the current state of conservation of } \\
\text { the classrooms - WINDOWS? }\end{array}$ \\
\hline Field Trip & $\begin{array}{r}\text { N } 10 \text { of } \\
\text { Respondents }\end{array}$ & $\begin{array}{c}\text { Percentage } \\
100 \%\end{array}$ \\
\hline Well & 0 & $0 \%$ \\
\hline Fair & 3 & $30 \%$ \\
\hline Bad & 7 & $70 \%$ \\
\hline TOTAL & 10 & $100 \%$ \\
\hline
\end{tabular}

Source: own elaboration.

Table 2 shows that $30 \%$ of the existing windows are in fair condition, and $70 \%$ are in poor condition.
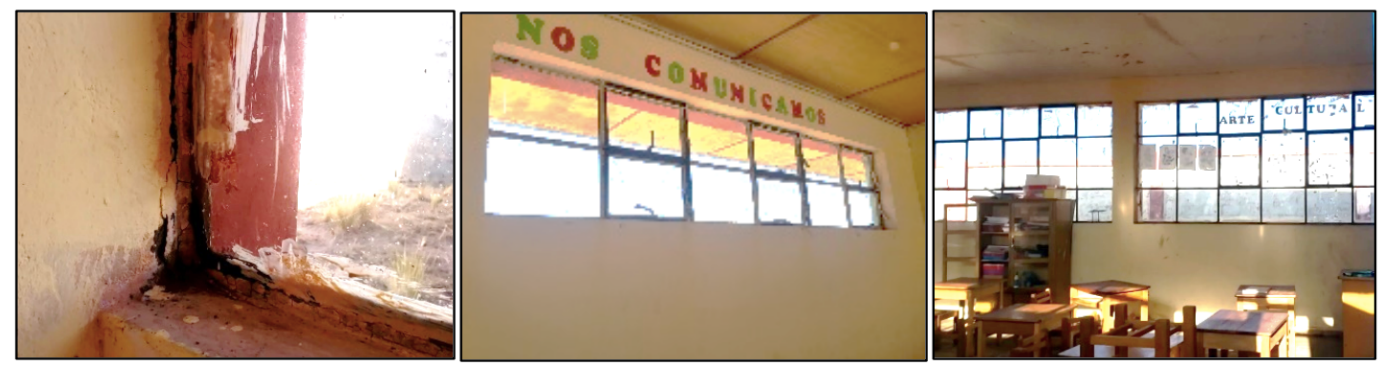

Figure 5. Existing windows.

Source: own elaboration. 
Figure 5 shows the casement windows with 1" iron frame "L" profile $+4 \mathrm{~mm}$ single glazing with deteriorated putty, with enamel paint stains on the front face.
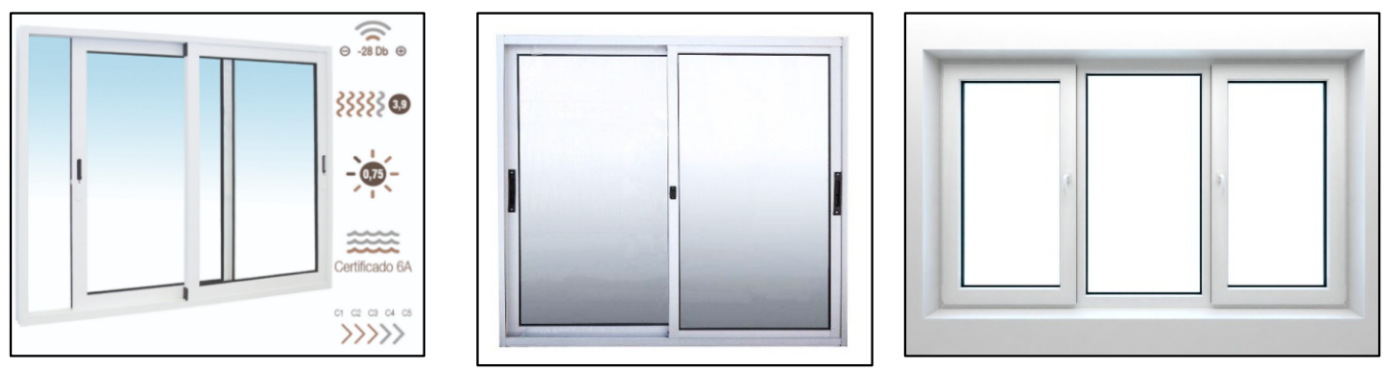

Figure 6. Double glazed windows with intervention.

Source: own elaboration.

Figure 6 shows the windows that were replaced, all single glazing to $4 \mathrm{~mm}$ double glazing, bonded with silicone +4 -micron security laminate. In addition, new sliding windows will be installed inside the classroom, with aluminum frames and $6 \mathrm{~mm}$ laminated glass. It will be placed $5 \mathrm{~cm}$ away from the existing window.

Table 3. Table of Existing Materials-False Ceiling Interior-Exterior.

\begin{tabular}{|c|c|c|}
\hline $\begin{array}{c}\text { 5.- What is the current state of preservation of the classrooms } \\
\text { - FALSE ROOFED ROOFED INTERIOR-EXTERIOR? }\end{array}$ \\
\hline Field Trip & $\begin{array}{c}\mathrm{N}^{\circ} 10 \text { of } \\
\text { Respondents }\end{array}$ & Percentage \\
\hline Well & 1 & $10 \%$ \\
\hline Fair & 2 & $30 \%$ \\
\hline Bad & 7 & $70 \%$ \\
\hline TOTAL & 10 & $100 \%$ \\
\hline
\end{tabular}

Source: own elaboration.

In Table 3, the existing interior floors of the classrooms, it can be seen that $10 \%$ of the interior-exterior false ceilings are in good condition, $20 \%$ are in fair condition and $70 \%$ are in a poor state of conservation (Simancas, 2003). 




Figure 7. Existing false ceiling: $4 \mathrm{~mm}$ plywood sheets, fixed to the lower part of the wooden scissors in $1.22 \mathrm{~m} x$ $1.22 \mathrm{~m}$ panels, joined with wooden flashing, with varnish paint finish.

Source: own elaboration.

\section{Materials Intervention- False ceiling, interior-exterior}
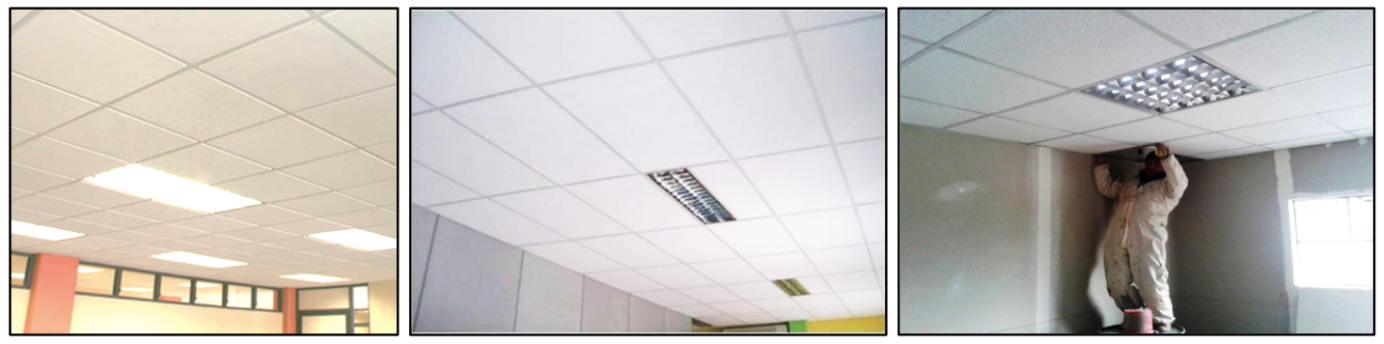

Figure 8. False interior ceiling with Intervention: New false ceiling made of aluminum profiles will be placed 10 $\mathrm{cm}$ away from the wooden purlins, where the new acoustic tile sheets will be installed with the aluminized side facing the ceiling + thermal insulation of Roca mineral wool, 2" blanket type + 6-micron plastic sleeve.

Source: own elaboration.

Table 7. Table of Existing Materials - Interior Walls.

\begin{tabular}{|c|c|c|}
\hline $\begin{array}{c}\text { 7.- What is the current state of conservation of } \\
\text { the classrooms - INTERIOR WALLS? }\end{array}$ \\
\hline Field trip & $\begin{array}{c}\mathrm{N}^{\circ} 10 \text { of } \\
\text { Respondents }\end{array}$ & $\begin{array}{c}\text { Percentage } \\
100 \%\end{array}$ \\
\hline Well & 0 & $0 \%$ \\
\hline Fair & 1 & $10 \%$ \\
\hline Bad & 9 & $90 \%$ \\
\hline TOTAL & 10 & $100 \%$ \\
\hline
\end{tabular}

Source: own elaboration.

Table 7, the existing interior walls of the classrooms, shows that $10 \%$ are in fair condition and $90 \%$ are in a poor state of conservation. 

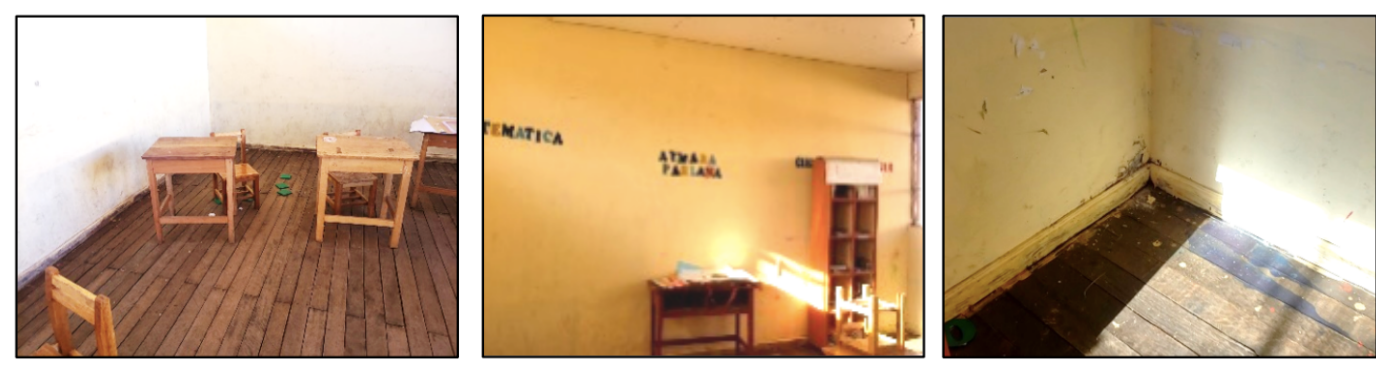

Figure 9. Existing walls: They are of confined masonry + latex paint, in a regular state of conservation. Source: own elaboration.

\section{Intervention Table - Interior Wall}
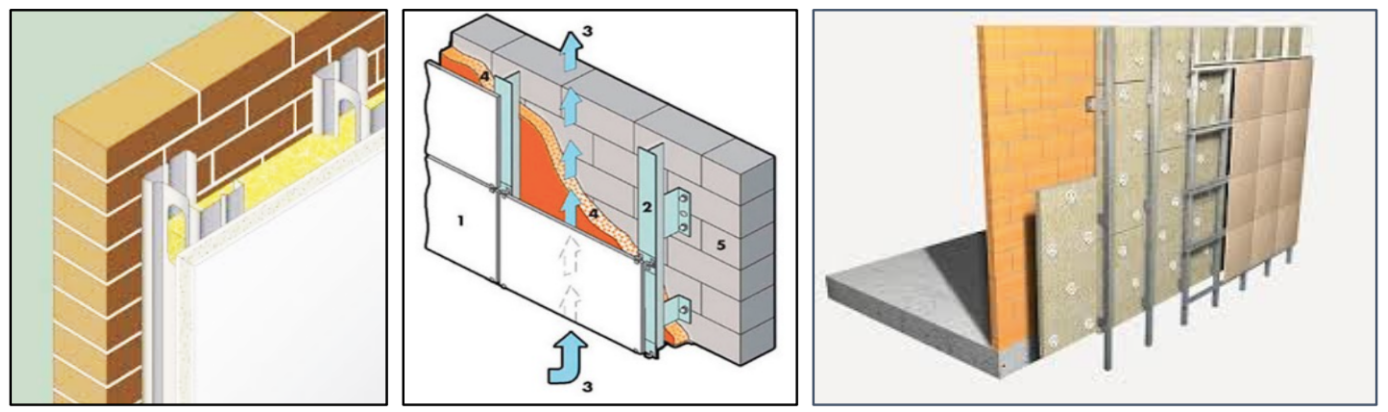

Figure 10. Double walls with Intervention: New $6 \mathrm{~mm}$ fiber cement wall, fixed to a 64 and $65 \mathrm{~mm}$. drywall metal structure, with interior thermal insulation of 2" mineral wool blanket + matte oil paint after applying base color and sealing of joints.

Source: own elaboration.

Once the state of conservation of the materials found and determining their state of preservation, we proceed to propose the New Materials that will replace or improve the existing materials of the Classroom, to achieve the Conditioning and Thermal Comfort inside the Classroom, to mitigate the cold of the area (Belón, 2018; Bojórquez, 2010). 



\section{VESTIBULE:}

2 Vestibules are planted, attached to the Classrooms. Both vestibules seek to control the sudden change of temperature between the outside environment and inside the classrooms. It is an intermediate space between the outside temperature and the inside temperature of each classroom.

Figure 11. New Environments to be Proposed.

Source: own elaboration.
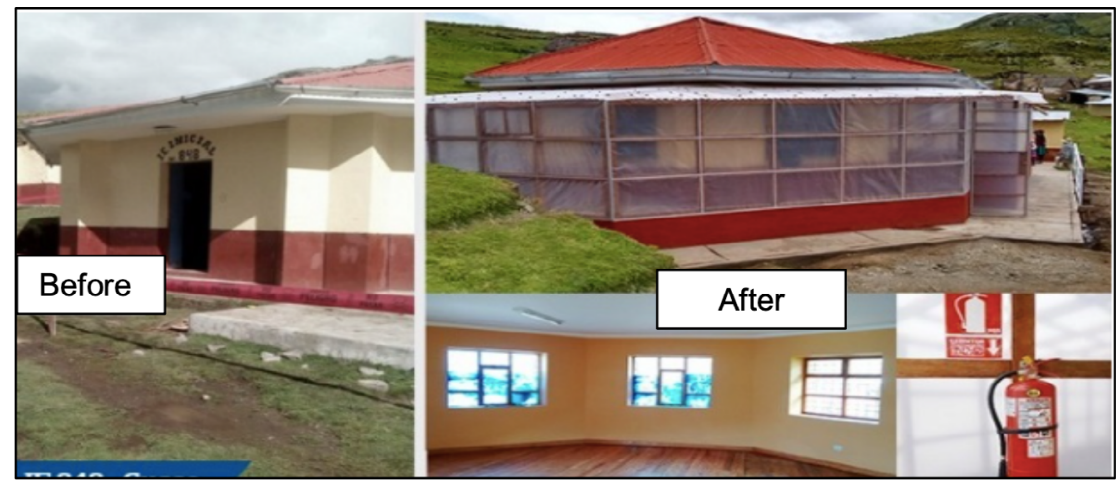

Figure 12. Double walls with intervention.

Source: own elaboration.

Likewise, we propose two new environments that will be attached to the classrooms and will serve to control the comfort inside the classrooms; in the back is the greenhouse lobby. 

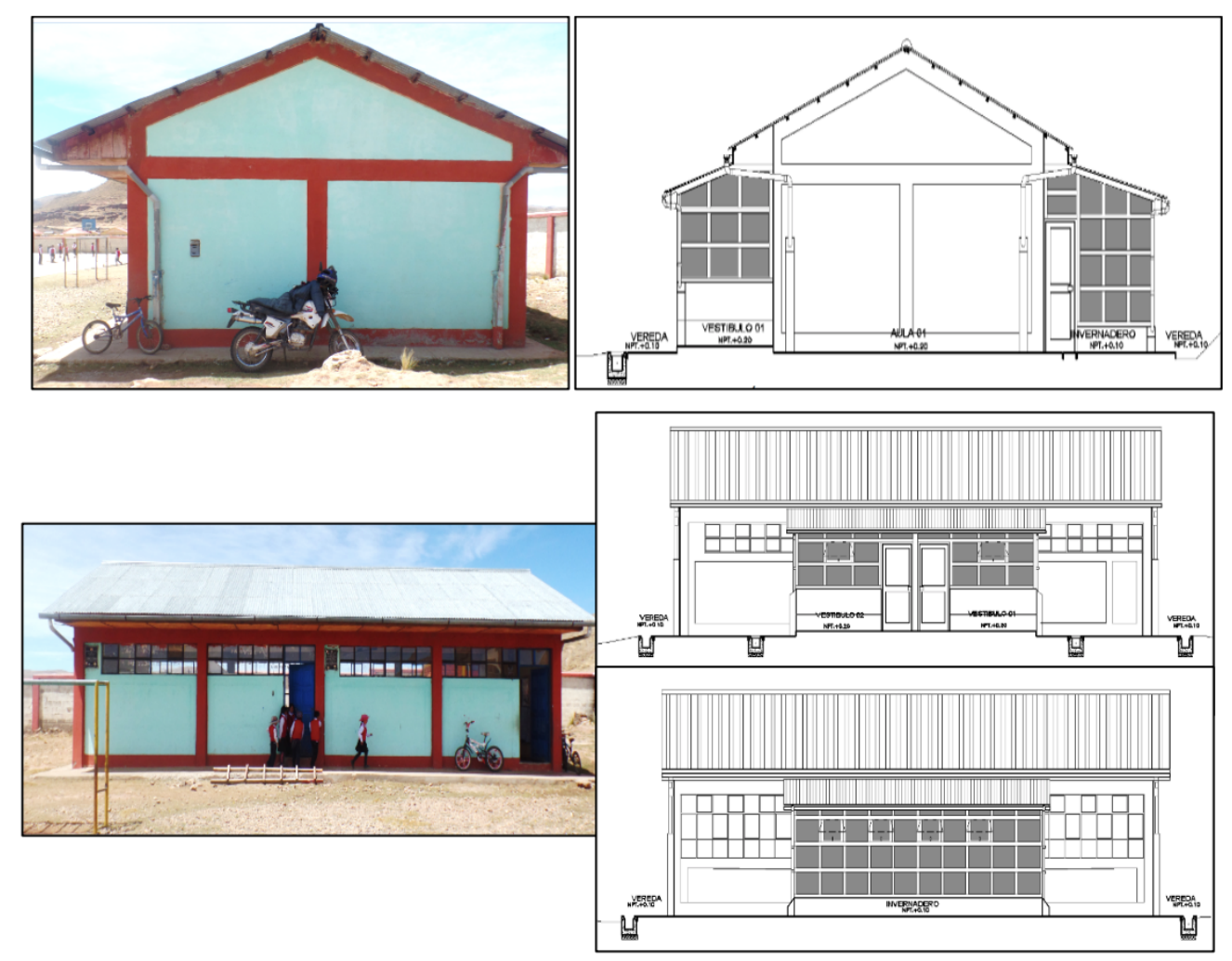

Figure 13. Existing Façades - Façades with Classroom Intervention.

Source: own elaboration.

Figure 13 shows the school before the modification on the left-hand side and the righthand side with the greenhouse. 


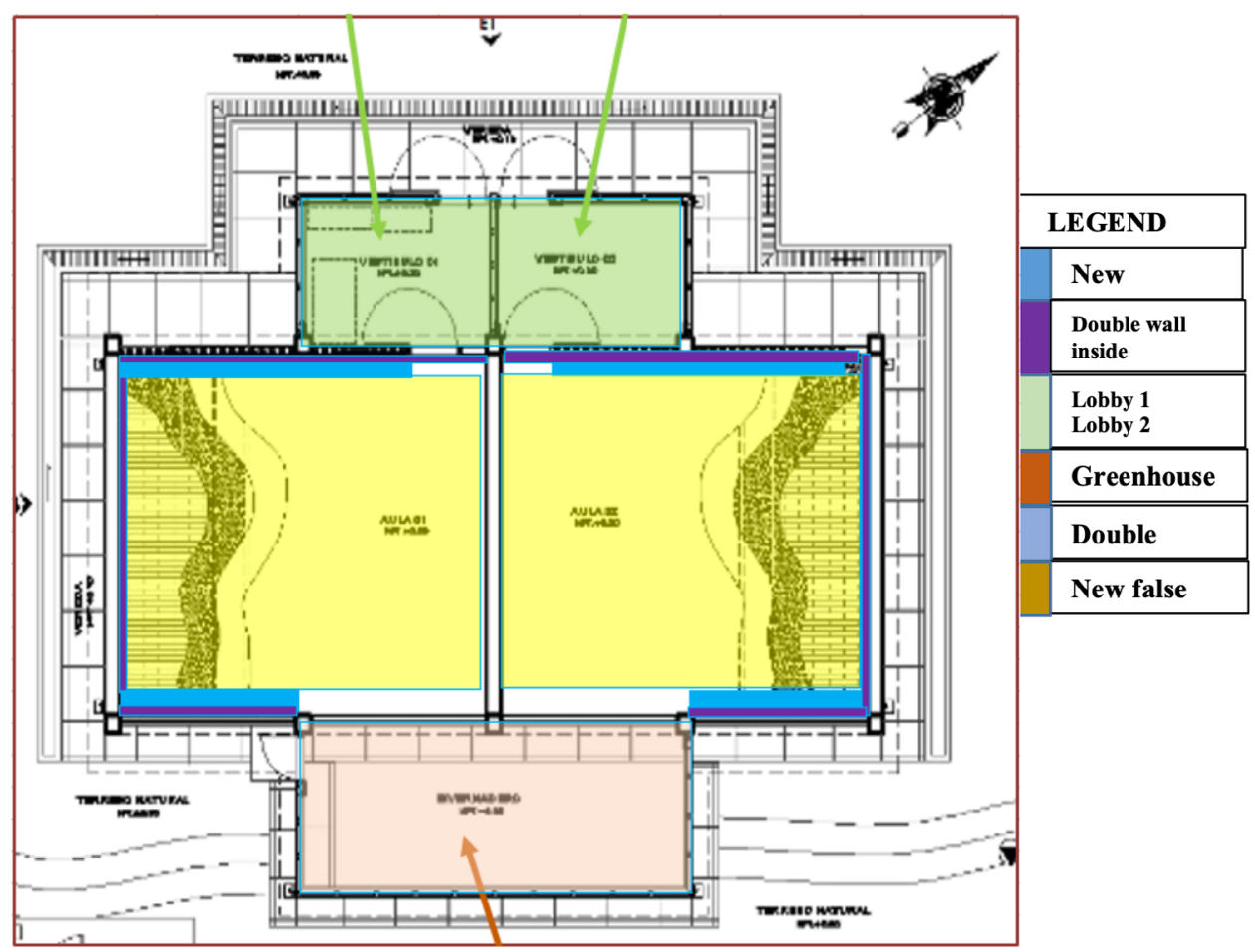

Figure 14. School with new materials.

Source: own elaboration.

Once the placement of the new materials has been completed, the temperatures inside the classrooms are taken every 2 hours and compared with the temperatures taken before the intervention of the classrooms.

\section{CONCLUSIONS}

The new double glazing and Greenhouse and Lobby windows must be controlled (Bakos \& Schiano-Phan, 2021).

When the sun heats up, which is from 7 a.m. to 2 p.m., the Greenhouse will heat up and transmit the heat to the interior of the classrooms.

To keep indoor classrooms comfortable in winter, the lobby doors should be kept closed. Likewise, the design of the façade is essential, which allows the capture of solar radiation and to be able to capture the energy from nature (Esenarro et al., 2020). 


\section{REFERENCES}

Bakos, N., \& Schiano-Phan, R. (2021). Bioclimatic and Regenerative Design Guidelines for a Circular University Campus in India. Sustainability, 13, 8238. https://doi. org/10.3390/su13158238

Belón, V. (2018). Propuesta de diseño de una casa rural térmica en zonas altoandinas de la región de Puno. Universidad andina Néstor Cáceres Velásquez.

Bojórquez, G. (2010). Confort Térmico en Exteriores: Actividades en Espacios Recreativos en Clima Cálido Seco Extremo. Universidad de Colima.

Esenarro, D., Escate, I., Anco, L., Tassara, G., \& Rodriguez, C. (2020). Proposal for an Ecological Research Center for the Recovery and Revaluation of Biodiversity in the Town of Quichas-Lima, Peru. International Fournal of Environmental Science and Development, 11(4), 212-216. http:/ /www.ijesd.org/vol11/1253-E2118.pdf

Esenarro, D., Rodriguez, G., Arteaga, J., Garcia, G., \& Flores, F. ( 2021). Sustainable Use of Natural Resources to Improve the Quality of Life in the Alto Palcazu Population Center, Iscozazin-Peru International Fournal of Environmental Science and Development, 12(5). http://www.ijesd.org/vol12/1332-SE1002.pdf

Flores, T., \& Quispe, M. (2017). Influencia del programa rincón literario para padres como estrategia para la participación en las actividades del aula de 4 años de la Lein ${ }^{\circ} 197$ "Huascar" de la ciudad de Puno, en el año 2016. Universidad Nacional del Altiplano de Puno.

Hinojosa, K., Esenarro, D., Mio, L. B., y Vasquez, W. (2021). Urban green areas to improve the quality of life in the San Juan de Miraflores district. 3C Tecnología. Glosas de innovación aplicadas a la pyme, Edición Especial, (mayo 2021), 135-147. https://doi. org/10.17993/3ctecno.2021.specialissue7.135-147

Manrique, G. (2019). Alojamiento Bioclimático En La Zona Agrícola De Rinconada De PuruhuayLurín. Universidad Ricardo Palma Facultad de Arquitectura y Urbanismo. https:// renati.sunedu.gob.pe/handle/sunedu/2008488

MINEDU. (2008). Guía de aplicación de arquitectura bioclimática en Locales educativos. Lima. 114p 
Norma EM.110. (2014). Confort Térmico y Lumínico con Eficiencia Energética. Ministerio de Vivienda, Construcción y Saneamiento. Lima. 50 p. https://cdn-web.construccion. org/normas/rne2012/rne2006/files/titulo3/04_EM/DS006-2014_EM.110.pdf

Quispe, E. (2013). Tecnologías de confort térmico en edificaciones de instituciones educativas de la zona altoandina de la región Puno. Universidad Nacional del Altiplano de Puno.

Quispe, R. (2015). Influencia del Aula Virtual En El Rendimiento Académico de los Estudiantes del Instituto Superior Tecnológico Privado. Universidad Nacional del Altiplano de Puno.

Simancas, K. (2003). Reacondicionamiento bioclimático de viviendas de segunda residencia en clima mediterráneo https:/ / www.tdx.cat/handle/10803/6113\#page=1

Umán, S., \& Méndez, M. (2019). Estrategias de climatización pasiva y confort térmico en la vivienda de adobe en la zona rural de Anta - Cusco, 2017. Universidad Ricardo Palma Facultad de Arquitectura y Urbanismo. https://repositorio.urp.edu.pe/bitstream/ handle/URP/2860/ARQ_T030_72945971_M\%20\%20\%20UM\%C3\%81N\%20 JUAREZ\%20STEVE\%20JASON.pdf? sequence $=1$ \&isAllowed $=\mathrm{y}$ 
